\title{
Невідкладні стани військовослужбовців з хірургічною бойовою травмою
}

\author{
М. І. Бадюк ${ }^{1}$, О. О. Микита ${ }^{1}$, І. П. Семенів ${ }^{2}$ В. В. Косарчук ${ }^{1}$, О. П. Михайлик ${ }^{3}$
}

1Українська військово-медична академія, м. Київ,

${ }^{2}$ Клінічна лікарня «Феофанія», м. Київ,

${ }^{3}$ Військово-медичне управління Головного управління Національної гвардії України, м. Київ

\section{Emergency states in military men with surgical armed trauma}

\author{
M. I. Badiuk ${ }^{1}$, O. O. Mykyta ${ }^{1}$, I. P. Semeniv ${ }^{2}$, V. V. Kosarchuk ${ }^{1}$, O. P. Mykhailyk ${ }^{3}$ \\ ${ }^{1}$ Ukrainian Military Medical Academy, Kyiv, \\ ${ }^{2}$ Clinical Hospital «Feofaniya», City of Kyiv, \\ ${ }^{3}$ Military-Medical Directorate of the Directorate-General of National Guard of Ukraine, Kyiv
}

\section{Реферат}

Мета. Дослідження актуальних невідкладних станів поранених військовослужбовців та обгрунтування необхідності застосування адаптованих алгоритмів і протоколів НАТО для організації хірургічної допомоги в медичному забезпеченні військ.

Матеріали і методи. Досліджено дані історій хвороб військовослужбовців, які проходили лікування в Національному військово-медичному клінічному центрі «Головний військовий клінічний госпіталь», із застосуванням статистичного, бібліографічного, проспективного та ретроспективного методів аналізу.

Результати. Проведеним дослідженням встановлено основні невідкладні стани військовослужбовців, що потребують медичної допомоги за сучасними алгоритмами і стандартами. Структуру невідкладних станів у військовослужбовців аналізували, порівнюючи показники до і після початку збройного конфлікту в Україні. Доведено, що кількість військовослужбовців, доставлених у тяжкому і вкрай тяжкому стані, після початку збройного конфлікту збільшилась на 48\% $3 а$ рахунок бойової хірургічної травми.

Висновки. Визначені актуальні невідкладні стани поранених, що є пріоритетними на догоспітальному етапі. Для вдосконалення організації хірургічної допомоги пораненим необхідні розробка і впровадження сучасних алгоритмів і протоколів за стандартами НАТО.

Ключові слова: військовослужбовці; невідкладні стани; бойова травма; медична допомога; алгоритми; протоколи; стандарти НАТО.

Abstract

Objective. Investigation of actual urgent states in the wounded military men and substantiation of necessity for application of the adopted algorithms and protocols of NATO for organization of surgical aid in medical supply of the troops.

Materials and methods. The histories of diseases data in military men were investigated, who were treated in National Military-Medical Clinical Center «Principal Military Clinical Hospital», using statistical, bibliographic, prospective and retrospective methods of analysis.

Results. The main emergency states in military men, demanding medical help in accordance to modern algorithms and standards, were established by the investigation. The emergency states structure in military men were analyzed, comparing indices before and after beginning of the armed conflict in Ukraine. There was proved, that the military men quantity, admitted to hospital in a severe and extremely severe state, after beginning of the armed conflict, have enhanced by $48 \%$ due to the armed surgical trauma. Conclusion. Actual priorities on prehostital stage of the emergency states for the wounded military men were determined. For improvement of the surgical aid organization to wounded military men it is necessary to elaborate and introduce the modern algorithms and protocols in accordance to NATO standards.

Keywords: military men; urgent states; operational trauma; medical aid; algorithms; protocols; standards of NATO.

Адаптація нормативно-правових актів України у сфері національної безпеки до євроатлантичних норм та стандартів висуває нові вимоги до медичного забезпечення Збройних Сил України (3СУ) [1, 2]. Збройний конфлікт на сході України значно прискорив усвідомлення необхідності удосконалення системи медичного забезпечення військ

Аналіз нормативно-правових документів медичної служби ЗСУ, сформованих з досвіду радянської армії, виявив низку невідповідностей їх сучасним поглядам на ефективну систему медичного забезпечення. Найперша невідповідність - це недооцінка важливості елемента першої (невідкладної) медичної допомоги, яку надають військовослужбовцю в перші хвилини після поранення (травмування) безпосередньо на полі бою та на перших етапах медичної евакуації. Наступна, не менш суттєва, на наш погляд, невідповідність - це брак у медичному забезпеченні медико-технологічних документів (алгоритмів, протоколів, стандартів надання медичної допомоги) щодо невідкладних станів військовослужбовців з бойовими травмами, отриманими в умовах збройного конфлікту, на догоспітальному етапі, призначених для лікарів, які надають 
допомогу на найперших етапах медичної евакуації, чи передових хірургічних груп (ПХГ) [3].

Як свідчить досвід медичного забезпечення антитерористичної операції, ураження військовослужбовців звичайними видами сучасної зброї призводять до тяжких наслідків, що спричинюють смерть поранених ще на полі бою або в перші години після поранення [4, 5]. Особливості патогенезу сучасних бойових уражень і захворювань військовослужбовців, їх тяжкість і вплив наявної коморбідності обумовлюють різноманітні ускладнення, що у свою чергу впливають на перебіг бойової травми чи захворювання в цілому і на прогноз для пацієнта.

Медичні служби збройних сил провідних країн світу, зокрема членів НАТО, особливу увагу приділяють процедурам надання невідкладної медичної допомоги військовослужбовцям, які грунтуються на практичному бойовому досвіді і найсильніших наявних медичних доказах і складність яких збільшується пропорційно кожному наступному рівню допомоги [6].

Зважаючи на зазначене, очевидною є необхідність удосконалення надання хірургічної допомоги військовослужбовцям $з$ тяжкою бойовою травмою відповідно до кращих світових стандартів.

Мета дослідження: обгрунтування потреби у напрацюванні ефективних медико-технологічних документів щодо надання екстреної і невідкладної хірургічної допомоги на догоспітальному етапі військовослужбовцям 3 невідкладними станами.

\section{Матеріали і методи дослідження}

Проведено проспективний та ретроспективний аналіз структури та характеру невідкладних станів, зумовлених сучасною бойовою патологією і захворюваннями, у військовослужбовців, які перебували на лікуванні в Національному військово-медичному клінічному центрі «Головний військовий клінічний госпіталь» (НВМКЦ «ГККГ») з 1999 по 2017 р. Усього було проаналізовано 191 731 історію хвороби, у тому числі 149334 - за період 3 1999 по 30 квітня 2014 р. та 42397 - за період з 1 травня 2014 по 2017 р. включно. Вибірку історій хвороб військовослужбовців у тяжкому і вкрай тяжкому стані для детального аналізу нозологій формували в два етапи: до 30 квітня 2014 р. (n=1347) і після 1 травня 2014 р. (n=544).

Проведено статистичне дослідження електронної бази даних історій хвороб військовослужбовців, які перебували на лікуванні в НВМКЦ «ГВКГ» 1999 по 2017 р. Для формування параметрів запитів щодо назв нозологічних форм та їх кількості використовували програму Microsoft Access. Із загальної кількості історій хвороб, що містились в електронній базі даних, через формування запитів нами відібрані історії хвороб усіх категорій військовослужбовців (офіцерів, прапорщиків, військовослужбовців строкової служби та військової служби за контрактом, мобілізованих тощо). Вибірки історій хвороб формували за нозологіями з урахуванням тяжкості стану військовослужбовців під час надходження на лікування та за строками надходження і виписки. 3 метою виявлення можливої відмінності у структурі тяжкості стану військовослужбовцівучасників бойових дій вибірки історій хвороб також розмежовані за часом - до 30 квітня 2014 р. (до першого надходження поранених) і після 1 травня 2014 р.

\section{Результати}

Відповідно до даних, наведених у табл. 1, за період 31 травня 2014 р. по 2017 р. кількість військовослужбовців, доставлених на лікування у легкому стані, дещо збільшилась, частина військовослужбовців, доставлених на лікування у стані середньої тяжкості, зменшилась, а частина військовослужбовців, доставлених на лікування у тяжкому і вкрай тяжкому стані, збільшилась суттево - на 48\% (р $\leq 0,001)$ порівняно з відповідними показниками за період з 1999 по 30 квітня 2014 р.

Надалі за допомогою програми Microsoft Excel було статистично визначено за класами захворювань частоту тяжких і вкрай тяжких станів військовослужбовців, яким надавали невідкладну медичну допомогу.

За результатами дослідження встановлено, що після 1 травня 2014 р. структура тяжких і вкрай тяжких станів військовослужбовців у зв'язку з надходженням на лікування поранених суттево змінилась (табл. 2). Більш як утричі (з 15,6 до 48,5\%) збільшилась частота тяжких і вкрай тяжких станів, зумовлених травмами та отруєнням (клас XIX). Натомість частота тяжких і вкрай тяжких станів, зумовлених хворобами органів дихання, зменшилась більш як утричі - 3 37,9 до 12,1\%. Частота виникнення тяжких і вкрай тяжких станів через хвороби системи кровообігу в обох періодах була майже однаковою - відповідно 7,4 та 7,8\%. Розлади психіки і поведінки зумовлювали тяжкі і вкрай тяжкі стани частіше після 1 травня 2014 р. - 6,1\%, ніж до 30 квітня 2014 р. - 4,3\%. Через хвороби органів травлення тяжкі і вкрай тяжкі стани, навпаки, виникали рідше після 1 травня 2014 р. - 5,2\%, ніж до 30 квітня 2014 р. - 7,1\%.

Наступним етапом статистичного дослідження було визначення найбільш важливих нозологічних форм травм

\begin{tabular}{|c|c|c|c|c|c|}
\hline Таблиця 1. & \multicolumn{5}{|c|}{$\begin{array}{l}\text { Порівняння структури тяжкості стану військовослужбовців у різні періоди надходження } \\
\text { на лікування }\end{array}$} \\
\hline & \multirow{3}{*}{ Ступінь тяжкості стану } & \multicolumn{4}{|c|}{ Період надходження військовослужбовців на лікування } \\
\hline & & \multicolumn{2}{|c|}{ з 1999 до 30 квітня 2014 р. } & \multicolumn{2}{|c|}{31 травня 2014 до 2017 p. } \\
\hline & & абс. & $\%$ & абс. & $\%$ \\
\hline Легкий & & 121910 & 81,6 & 36236 & 85,5 \\
\hline \multicolumn{2}{|c|}{ Середньої тяжкості } & 26077 & 17,5 & 5617 & 13,2 \\
\hline \multicolumn{2}{|c|}{ Тяжкий } & 1260 & 0,8 & 510 & 1,2 \\
\hline \multicolumn{2}{|c|}{ Вкрай тяжкий } & 87 & 0,06 & 34 & 0,08 \\
\hline \multicolumn{2}{|c|}{ Усього ... } & 149334 & 100 & 42397 & 100 \\
\hline
\end{tabular}




\begin{tabular}{|c|c|c|}
\hline $\begin{array}{l}\text { Порівняння частоти виникнення невідкладних с } \\
\text { захворювань (\%) }\end{array}$ & військовослужб & окремими класами \\
\hline \multirow{2}{*}{ Клас захворювань за МКХ-10 } & \multicolumn{2}{|c|}{ Період надходження військовослужбовців на лікування } \\
\hline & до 30 квітня 2014 р. & після 1 травня 2014 р. \\
\hline Клас І. Деякі інфекційні та паразитарні хвороби & 9,7 & 3,7 \\
\hline Клас V. Розлади психіки та поведінки & 4,3 & 6,1 \\
\hline Клас VI. Хвороби нервової системи & 4,3 & 2,4 \\
\hline Клас IX. Хвороби системи кровообігу & 7,8 & 7,4 \\
\hline Клас Х. Хвороби органів дихання & 37,9 & 12,1 \\
\hline Клас ХІ. Хвороби органів травлення & 7,1 & 5,2 \\
\hline Клас XIX. Травми, отруєння та деякі інші наслідки дії зовнішніх причин & 15,6 & 48,5 \\
\hline Клас XX. Зовнішні причини захворюваності та смертності & 3,9 & 4,4 \\
\hline Клас XXI. Фактори, що впливають на стан здоров'я населення & 1,3 & 2,0 \\
\hline Інші не вказані класи разом & 8,1 & 8,2 \\
\hline Усього $\ldots$ & 100 & 100 \\
\hline
\end{tabular}

(у тому числі й бойових) та захворювань, що зумовлюють невідкладні стани військовослужбовців, у межах наведених класів захворювань.

Виявлено, що в межах XIX класу «Травми, отруєння та деякі інші наслідки дії зовнішних причин» після 1 травня 2014 р. здебільшого поєднані поранення і травматичні пошкодження голови та головного мозку зумовлювали тяжкі і вкрай тяжкі стани військовослужбовців з частотою 27,3\%, травми органів черевної порожнини - 18,2\%, травми грудної клітки і ребер - 12,9\%. Після травм кульшових суглобів частота тяжких і вкрай тяжких станів військовослужбовців становила 7,2\%, вогнепальних переломів довгих трубчатих кісток - 6,4\%.

Структура, локалізація і тяжкість травматичних пошкоджень у поранених, встановлені нами, в цілому співвідносяться $з$ даними досліджень, що містять аналіз структури тяжкості бойової травми поранених військовослужбовців у найбільших збройних конфліктах останніх років $[7,8]$.

Враховуючи дані аналізу невідкладних станів військовослужбовців у бойових умовах, ми здійснили спробу оцінити можливість адаптації і застосування щодо даної ситуації медико-технологічних документів Міністерства охорони здоров'я України (МО3 України) як центрального органу виконавчої влади, що забезпечує формування та реалізацію державної політики у сфері охорони здоров'я та затверджує галузеві стандарти у сфері охорони здоров'я, зокрема клінічні протоколи і стандарти, здійснює контроль за їх дотриманням [9]. Проте медико-технологічних документів стосовно бойової патології, затверджених МОЗ України, знайдено не було.

\section{Обговорення}

Беручи до уваги результати проведених досліджень щодо актуальних невідкладних станів військовослужбовців, ми використали наявні медико-технологічні документи стосовно медичної допомоги при бойовій патології країн НATO, зокрема STANAG 2549 (AMedP-24) «Emergency care in the operational environment» та польове керівництво FM 4-02.25 Field Manual 4-02.25 «Employment of forward surgical teams: tactics, techniques and procedures» [10, 11]. Були адаптовані алгоритми надання екстреної медич- ної допомоги військовослужбовцям, що можуть використовуватись у практичній роботі лікарів та медичного персоналу 3СУ, які надають медичну допомогу пораненим на догоспітальному етапі (роль 1) в бойових умовах [12].

На думку фахівців [3], формування і розгортання ПХГ на передових етапах медичної евакуації (роль 1) та застосування сучасних протоколів надання хірургічної допомоги пораненим з метою збереження життя і стабілізації стану мають суттєво підвищити ефективність надання медичної допомоги пораненим у цілому. Проте в такому разі одним з основних обов'язкових елементів є застосування передових медичних технологій і методик. Зокрема, як наведено в польовому керівництві [11], для хірургічних втручань на передових етапах медичної евакуації (роль 1) в країнах НАТО прийнято 57 кодів бойових травм, що супроводжуються невідкладними станами. Визначено показання до хірургічних втручань. ПХГ повинні виконувати тільки процедури, які необхідні, щоб стабілізувати стан постраждалого для подальшої евакуації. ПХГ, як правило, не надають хірургічну допомогу в повному обсязі, вони здійснюють тільки заходи, спрямовані на врятування життя і здоров'я пацієнта, запобігання інфекції та забезпечення його транспортабельності. Хірургічних процедур, які не $€$ необхідними для реанімації та стабілізації стану пацієнта, слід уникати. Така концепція дає змогу ПХГ підтримувати передбачену для них мобільність.

Концептуальні блоки польового керівництва побудовано за важливістю і вагою невідкладних станів поранених. У розділі «Загальна хірургія» чільне місце займають протоколи відновлення прохідності дихальних шляхів, керівні принципи для анестезіі, хірургічної обробки ран та надання нейрохірургічної допомоги. Важливий розділ присвячено ортопедичним аспектам хірургії та хірургічним втручанням при опіках.

\section{Висновки}

1. В умовах збройного конфлікту до найбільшої частоти (48,5\%) виникнення тяжких і вкрай тяжких станів військовослужбовців призводять нозологічні форми, об'єднані в класі XIX «Травми, отруєння та деякі інші наслідки дії зовнішніх причин». Найчастіше спричиняють невідклад- 
ні стани військовослужбовці такі нозологічні форми бойових травм: поранення і травматичні пошкодження голови і головного мозку (27,3\%), травми органів черевної порожнини (18,2\%), травми грудної клітки і ребер (12,9\%).

2. 3 огляду на те, що в Україні немає медико-технологічних документів щодо надання хірургічної допомоги пораненим на догоспітальному етапі (роль 1), медичним забезпеченням сил оборони мають бути адаптовані алгоритми і протоколи, розроблені за стандартами НАТО.

\section{References}

1. Ukaz Prezydenta Ukrainy. Pro rishennia Rady natsionalnoi bezpeky i oborony Ukrainy vid 2016 May 20 Pro Stratehichnyi oboronnyi biuleten Ukrainy [Internet]. 2016 May 20; 240. [cited 2016 Jan 6]. Available from: http://www.president.gov.ua/documents/2402016-20137. [In Ukrainian].

2. Ukaz Prezydenta Ukrainy. Pro rishennia Rady natsionalnoi bezpeky oborony Ukrainy. Pro novu redaktsiiu Voiennoi doktryny Ukrainy [Internet]. 2015 Sap 24; 555. [cited 2015 Sap 24]. Available from: http:// zakon3.rada.gov.ua/laws/show/555/2015. [In Ukrainian].

3. Verba AV. Stan ta problemni pytannia medychnoho zabezpechennia $v$ zoni provedennia antyterorystychnoi operatsii v rizni periody. Medychne zabezpechennia antyterorystychnoi operatsii: naukovo-orhanizatsiini ta medyko-sotsialni aspekty. 2016;45:15-27. [In Ukrainian].

4. Badiuk MI, Mykyta OO, Shvets AV, Sereda IK, Kovyda DV, et al. Analiz roboty medychnoi sluzhby shchodo priorytetnykh napriamkiv rozrobky ta vprovadzhennia standartiv medychnoho zabezpechennia Zbroinykh Syl Ukrainy na osoblyvyi period. Problemy viiskovoi okhorony zdorovia. 2016;45:9-16. [In Ukrainian].
5. Badiuk MI, Kovyda DV. Spromozhnist svoiechasnoho nadannia medychnoi dopomohy na etapakh medychnoi evakuatsii taktychnykh pidrozdiliv sukhoputnykh viisk. Problemy viiskovoi okhorony zdorovia. 2013;37:115. [in Ukrainian].

6. AJP-4.10(A). Allied joint medical support doctrine, 2006. Reference of decision for release: NSA(MED)0562(2011)1/MedSB dated 2011 May 30): $98 \mathrm{p}$.

7. Patel TH, Wenner KA, Price SA, Weber MA, Leveridge A, McAtee SJ A U.S. Army Forward Surgical Team's experience in Operation Iraqi Freedom. J Trauma. 2004 Aug;57(2):201-7. PMID: 15345962.

8. Counihan TC, Danielson PD. The 912th forward surgical team in Operation New Dawn: employment of the forward surgical team during troop withdrawal under combat conditions. Mil Med. 2012 Nov; 177(11): 1267-71. PMID: 23198500.

9. Postanova Kabinetu Ministriv Ukrainy. Pro zatverdzhennia polozhennia pro Ministerstvo okhorony zdorovia Ukrainy [Internet]. 2015 March 25;267. [updated 2018 Jan 10]. Available from: http://zakon2.rada.gov. ua/ laws/show/267-2015-p. [In Ukrainian].

10. NATO STANAG 2549 - AMedP-24: Emergency care in the operational environment. 2011; 348 p.

11. Department of the Army Washington. FM 4-02.25 (FM 8-10-25). Employment of forward surgical teams. Tactics, techniques, and procedures. [Internet]. 2003 March 28. Available from: https://archive.org/stream/

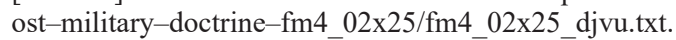

12. Badiuk MI, editor. Ekstrena medychna dopomoha viiskovosluzhbovtsiam na dohospitalnomu etapi v umovakh zbroinykh konfliktiv. Kyiv: SPD Chalchynska N.V.; 2018. 204 p. [In Ukrainian]. 